\title{
Life-cycle of Scinaia interrupta (Nemaliales, Rhodophyta)
}

Karla León-Cisneros, Eunice M. Nogueira, Rafael Riosmena-Rodríguez \& Ana Isabel Neto

Journal of Applied Phycology

ISSN 0921-8971

Volume 23

Number 3

J Appl Phycol (2011)

23:467-473

DOI $10.1007 /$

s10811-010-9605-8

\section{JOURNAL OF APPLIED PHYCOLOGY}

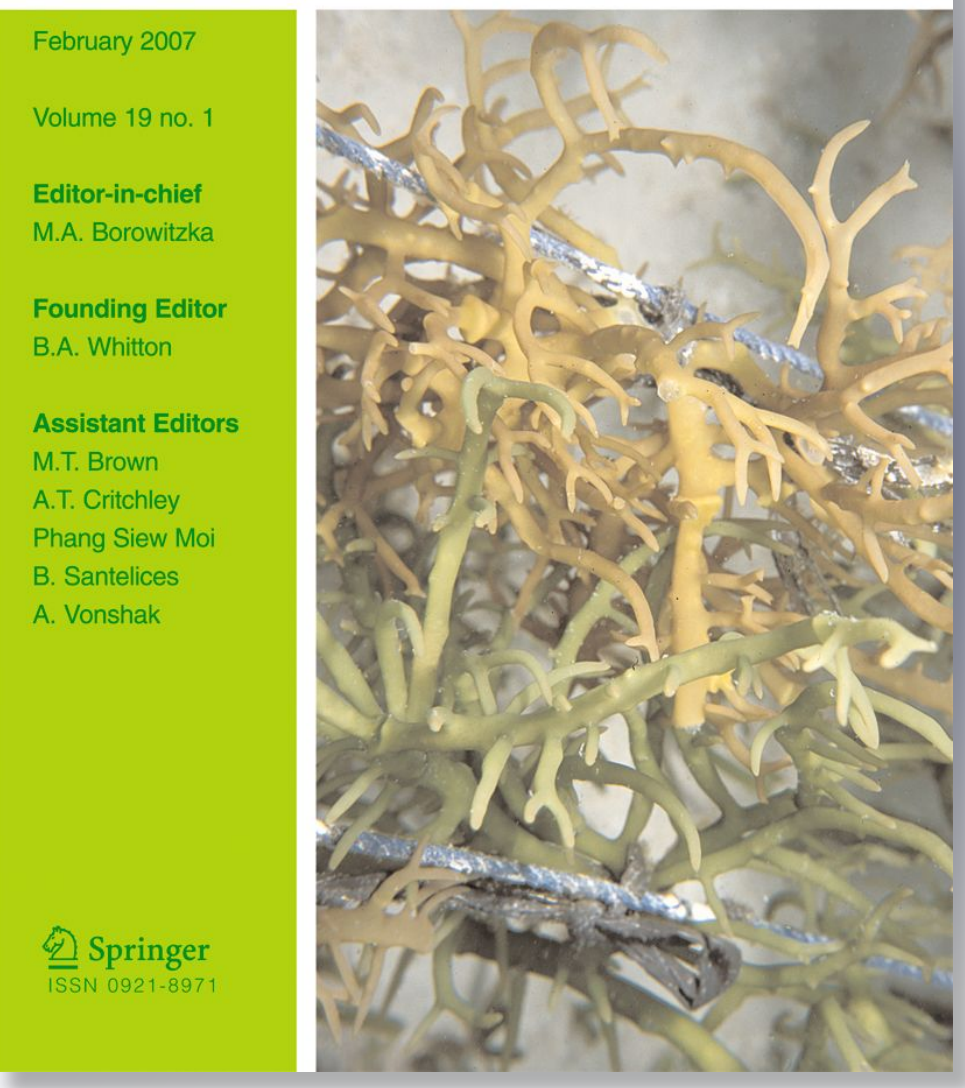

\section{望 Springer}


Your article is protected by copyright and all rights are held exclusively by Springer Science+Business Media B.V.. This e-offprint is for personal use only and shall not be selfarchived in electronic repositories. If you wish to self-archive your work, please use the accepted author's version for posting to your own website or your institution's repository. You may further deposit the accepted author's version on a funder's repository at a funder's request, provided it is not made publicly available until 12 months after publication. 


\title{
Life-cycle of Scinaia interrupta (Nemaliales, Rhodophyta)
}

\author{
Karla León-Cisneros • Eunice M. Nogueira • \\ Rafael Riosmena-Rodríguez • Ana Isabel Neto
}

Received: 15 March 2010/Revised and accepted: 24 September 2010/Published online: 12 October 2010

(C) Springer Science+Business Media B.V. 2010

\begin{abstract}
The life-cycle of Scinaia interrupta (A.P. de Candolle) M. J. Wynne was investigated in vitro using four irradiance regimes: 4, 8, 12 and $16 \mu \mathrm{mol}$ photons $\mathrm{m}^{-2} \mathrm{~s}^{-1}$. A triphasic heteromorphic life-cycle was observed. Carpospores released by cystocarps of gametophytes collected in the field developed into filamentous tetrasporophytes, which produced tetrahedral tetrasporangia. Tetrasporangial development was accelerated under higher irradiance levels. Tetraspores germinated into filamentous protonemal gametophytes, initially identical to the tetrasporophyte. Filamentous gametophytes developed apical utricles and gave rise directly to the fleshy gametophyte. Further development of the fleshy gametophyte was not observed at the lowest irradiance regime $\left(4 \mu \mathrm{mol}\right.$ photons $\left.\mathrm{m}^{-2} \mathrm{~s}^{-1}\right)$. The present study reports for the first time the influence of the irradiance regime on the initial tetrasporangial development and in the development of the fleshy gametophyte, and reinforces the importance of light intensity on Scinaia
\end{abstract}

K. León-Cisneros • E. M. Nogueira · A. I. Neto

CIIMAR (Centro Interdisciplinar de Investigação Marinha e

Ambiental), Universidade do Porto,

Rua dos Bragas,

289-4050-123 Porto, Portugal

K. León-Cisneros • E. M. Nogueira • A. I. Neto

CIRN and Grupo de Biologia Marinha, Departamento Biologia,

Universidade dos Açores,

Rua Mãe de Deus 58, Apart. 1422,

9502 Ponta Delgada, São Miguel, Açores, Portugal

K. León-Cisneros $(\triangle) \cdot R$. Riosmena-Rodríguez Programa de Investigación en Botánica Marina, Universidad Autónoma de Baja California Sur, Apartado Postal 19-B,

La Paz C.P. 23080 BCS, Mexico

e-mail: kcisneros@uac.pt life-cycle. Production of apical utricles by the filamentous gametophyte is newly reported for the genus.

Keywords Filamentous tetrasporophyte $\cdot$ Filamentous protonemal gametophyte $\cdot$ In vitro life-history studies . Irradiance regimes $\cdot$ New development phase $\cdot$ Scinaia

\section{Introduction}

Knowledge on life histories in Nemaliales is only partial or inferred from reproductive status of field collected specimens. A markedly heteromorphic life-history is reported for the families Liagoraceae and Scinaiaceae with a crustose (Nothogenia) or filamentous (Scinaia, Gloiophloea) tetrasporophyte, alternating with a fleshy gametophyte (e.g., Anderson and Stegenga 1985; Huisman 1987). An isomorphic life-history, with phases structurally dimorphic, is reported for the family Galaxauraceae based on the observations of the reproductive structures and in the similar gross morphology of wild material (e.g., Huisman and Borowitzka 1990); molecular data has been used as direct evidence of tetrasporophyte and gametophyte conspecificity (Kurihara et al. 2005).

Life-history studies of Scinaia have been few, with only six species investigated in culture. A triphasic heteromorphic life-cycle including a filamentous tetrasporophyte and a filamentous protonemal gametophyte, from which the fleshy gametophyte develops, was reported in four species: Scinaia confusa (Setchell) Huisman (Ramus 1969), Scinaia furcellata (Turner) J. Agardh (Boillot 1968, 1969), Scinaia complanata (F. S. Collins) Cotton (van den Hoek and Cortel-Breeman 1970), and Scinaia halliae (Setchell) Huisman (Aguilera and Ganesan 1981). A filamentous tetrasporophyte was also reported in Scinaia interrupta (as 
Scinaia turgida) and Scinaia japonica Setchell (Boillot 1971a; Umezaki 1972) but the complete life-cycle is still unknown.

Scinaia interrupta (Scinaiaceae, Nemaliales) is known in the eastern Atlantic from the British Isles (up to Shetland Is.) to Morocco (Maggs and Guiry 1982; Guiry and Guiry 2009), and also from the Gulf of California (León-Cisneros et al. 2009). Worldwide, this species has a seasonal occurrence, and is found subtidally in sandy environments, rocky bottoms with sand influence and rhodolith beds (Maggs and Guiry 1982; León-Cisneros et al. 2009). Only gametangial plants are reported in the wild. The gametophyte is characterized by an erect cylindrical to ellipsoidal fleshy red thallus, up to $10 \mathrm{~cm}$ in height and dichotomously branched. The external cortex is composed of polygonal colorless utricles. Reproduction is monoecious, with spermatangia scattered along the thallus surface, not forming sori, and cystocarps having rhizoidal filaments (León-Cisneros et al. 2007, 2009).

In the present study, the life-cycle of S. interrupta was investigated in vitro, using different irradiance regimes, and a new phase of the gametophyte development is described for the genus.

\section{Material and methods}

The occurrence of wild gametophytes of S. interrupta in the Azores is restricted to the period between May and July. Plants were collected in June and July 2008 from sandyrocky habitats between 12 and $18 \mathrm{~m}$ depth, at Porto de Santa Iria on the island of São Miguel by SCUBA-diving, and were numbered (code numbers: SMG-08-14, SMG-0862 to SMG-08-69) and housed at AZB, herbarium of the University of the Azores (herbarium abbreviations as in Holmgren and Holmgren 1998). Reference collections of sporophytes and gametophytes developed in culture were also made.

Cultures were initiated from carpospores released from mature carposporophytes of one plant collected in June and eight collected in July. Segments of the gametophytes containing cystocarps were cut out, washed with sterile seawater, and placed in Petri dishes containing sterile seawater. To promote the release of carpospores, fragments were stressed using temperature and light, following Vergés et al. (2004): they were kept for $24 \mathrm{~h}$ in complete darkness at $15^{\circ} \mathrm{C}$, followed by $24 \mathrm{~h}$ at $60-64 \mu \mathrm{mol}$ photons $\mathrm{m}^{-2} \mathrm{~s}^{-1}$ at $23^{\circ} \mathrm{C}$. Carpospores were inoculated with a sterilized glass Pasteur pipette onto $22 \times 22 \mathrm{~mm}$ glass coverslips inside Petri dishes, and grown in quarter-strength modified von Stosch's medium (Guiry and Cunningham 1984). Diatom growth was controlled with $\mathrm{GeO}_{2}\left(0.25 \mathrm{mg} \mathrm{L}{ }^{-1}\right)$ and (cyano-) bacterial growth with Penicillin-G $\left(0.1 \mathrm{~g} \mathrm{~L}^{-1}\right)$. The medium was changed fortnightly. Cultures were kept inside incubators equipped with cool-white fluorescent tubes (Phillip TL-D $18 \mathrm{~W} / 54-765)$. Irradiances were measured using a LI-COR light meter (LI-250A) with a spherical quantum sensor (LI-193).

All carpospores were cultured during the first 2 months at $18^{\circ} \mathrm{C}, 16: 8 \mathrm{~h}(\mathrm{~L}: \mathrm{D})$ and $16 \mu \mathrm{mol}$ photons $\mathrm{m}^{-2} \mathrm{~s}^{-1}$ and then split into four irradiance regimes: $4,8,12$ and $16 \mu \mathrm{mol}$ photons $\mathrm{m}^{-2} \mathrm{~s}^{-1}$, keeping the same temperature and photoperiod. For each original plant, two to three replicate Petri dishes were prepared and assigned to each regime. Cultures were examined every $2-5$ days in the first development stages and subsequently once per week. Released tetraspores were isolated following the same procedure used for the inoculation of carpospores.

Growth and reproductive states of the cultured plants were monitored with an inverted microscope. Photographs were taken using a digital camera attached either to the inverted microscope or to a conventional light microscope. Measurements of cells and structures were taken with the software AxioVision LE 4.2 from the digital photographs.

\section{Results}

The mature carposporophytes of $S$. interrupta were found in brilliant pink gametophytes of 3 to $10 \mathrm{~cm}$ (Fig. 1). After the stress treatment, the carpospores were released and attached to the glass coverslips in Petri dishes (Fig. 2a). Released carpospores were spherical, $8-11 \mu \mathrm{m}$ in diameter and with a thin hyaline coating of mucilage. Within $24 \mathrm{~h}$ to 7 days of attachment, one small protrusion (Fig. 2a)

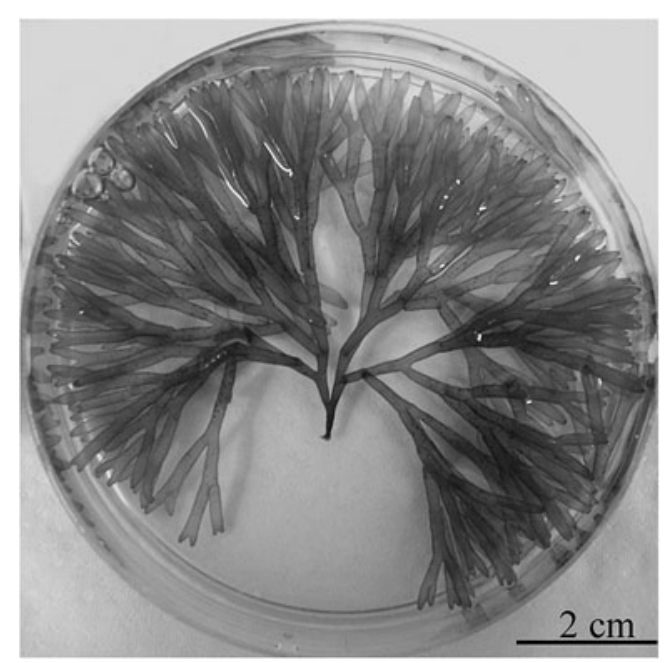

Fig. 1 Gametophyte of Scinaia interrupta, SMG-08-69 


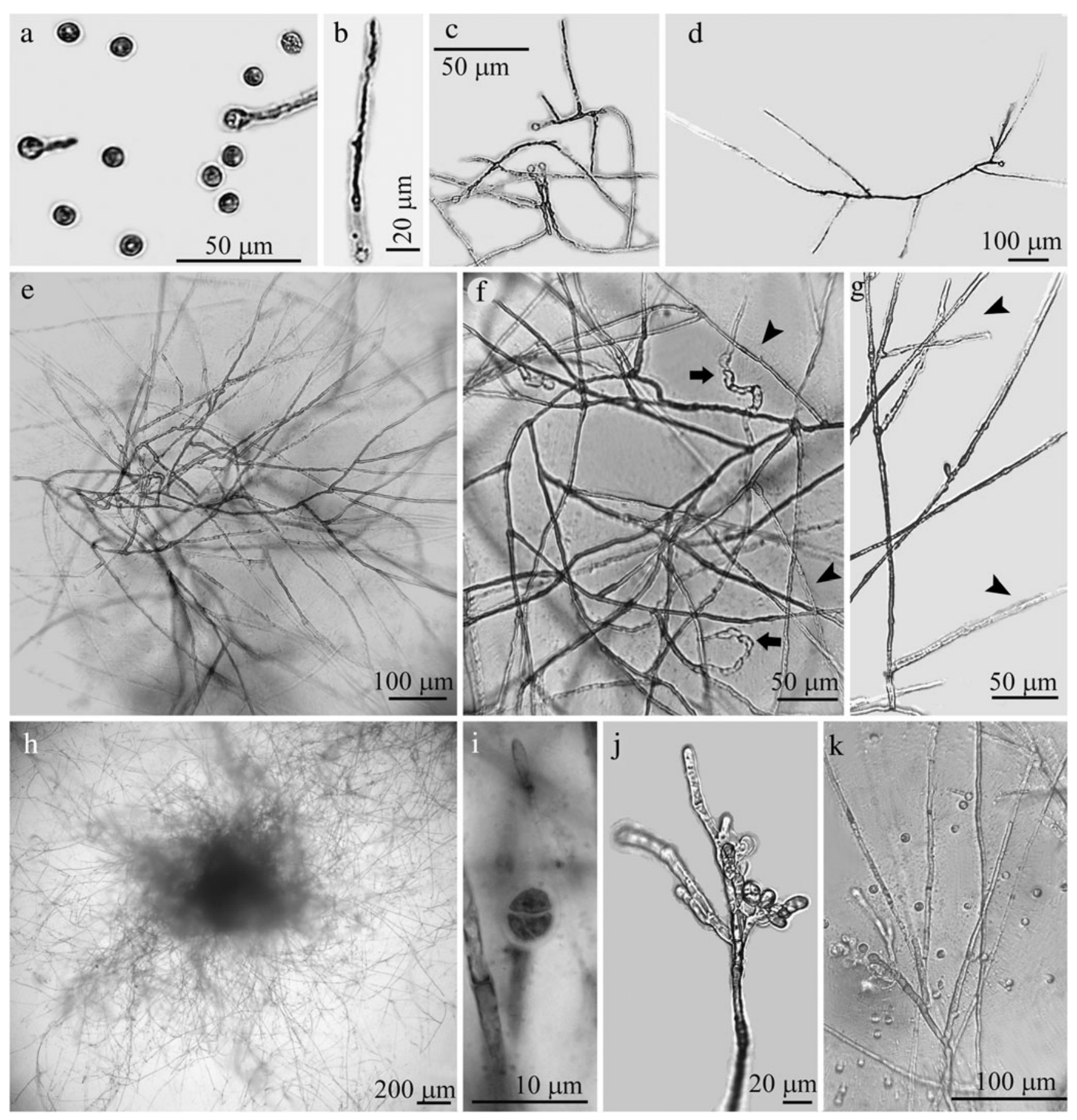

Fig. 2 S. interrupta sporophyte development. a Released carpospores; b Germinating carpospores, 2 days old; c-e Filaments development, 15 days old (c), 34 days old (d), 7 weeks old (e); $\mathbf{f}-\mathbf{g}$ Prostrate filaments (f) and apexes (g) detail, showing basal twisted filaments (arrows) and hair-like apex (arrowheads); h habit of tetrasporophyte; $\mathbf{i}-\mathbf{j}$ tetrahedral tetrasporangia, solitary (i) or in group (j); $\mathbf{k}$ released tetraspores and empty tetrasporangia

tetrasporangia (15-20 $\mu \mathrm{m}$ long and 14-16 $\mu \mathrm{m}$ wide) grew terminally, solitary, or in groups (Fig. 2i-j). Tetrasporangium development and tetraspore release (Fig. 2k) were observed for all irradiance regimes, but sporogenesis was accelerated by higher irradiance levels (Fig. 3). Tetrasporophytes produced and released tetraspores continuously for 


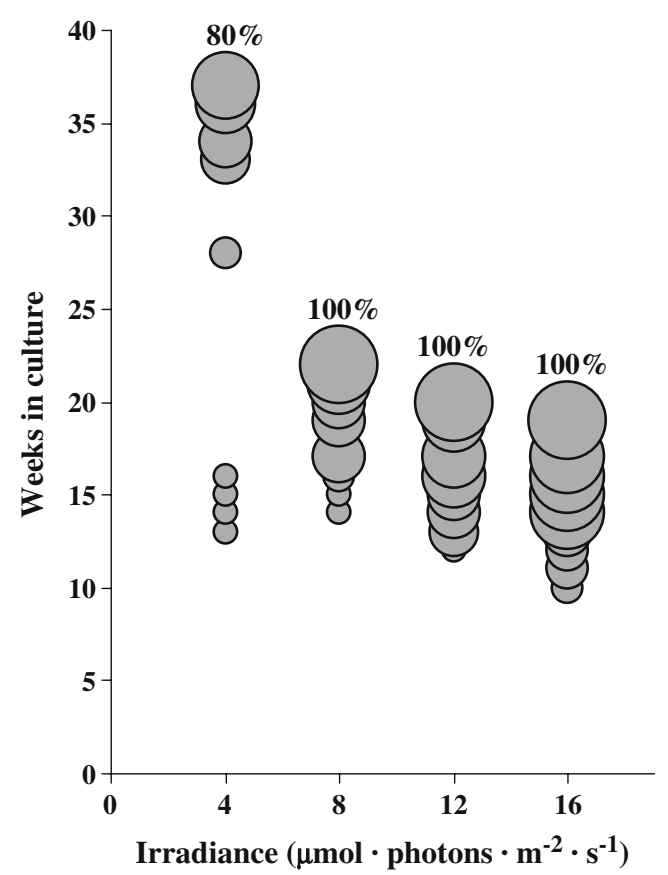

Fig. 3 Effects of irradiance on tetrasporangium formation in $S$. interrupta. Diameter of the bubbles indicates percentage of Petri dishes with tetrasporangia

1 to 4 months. After 10 months in culture, the erect filaments were lost or colorless and the prostrate filaments were strongly colored and crust-like. Monosporangium development was not observed.

Released tetraspores were spherical, $8-10 \mu \mathrm{m}$ in diameter (Fig. 2k), and germinated into a filamentous profusely branched plant (protonemal gametophyte, Fig. 4a), only distinguishable from the tetrasporophyte after 3 months of development, when buds and/or apical utricles were produced (Fig. $4 \mathrm{~b}-\mathrm{g}$ ). In the lowest irradiance regimes (4 $\mu$ mol photons $\mathrm{m}^{-2} \mathrm{~s}^{-1}$ ), buds development was not observed. In the remaining regimes, buds started as enlarged pigmented lateral cells of the filaments (Fig. 4d) with an evident mucilage cover (Fig. 4e-f), that developed into central filaments and utricles (Fig. 4g). After 3 weeks, the initial protonemal gametophyte hosted one (Fig. 4h) to several (Fig. 4i) fleshy outgrowths, with morphology and anatomy similar to field collected gametophytes.

A triphasic heteromorphic life-cycle was thus observed in S. interrupta from the Azores (Fig. 5), with the meiosis occurring presumably in the formation of the tetraspores: the fleshy gametophyte (1) after fertilization produced carposporophytes (2); the released carpospores germinated into a filamentous tetrasporophyte (3). Released tetraspores germinated into a filamentous protonemal gametophyte initially morphologically similar to the tetrasporophyte but with apical utricles. The fleshy gametophyte arose directly from the filamentous protonemal stage. This whole cycle development took from 5 to 11 months, the variation proceeding from the effect of irradiance on tetrasporogenesis.

\section{Discussion}

The complete life-cycle of $S$. interrupta is here described and illustrated for the first time. This species revealed a triphasic heteromorphic life-cycle similar to the one described for other species of Scinaia (see Boillot 1968, 1969; Ramus 1969; van den Hoek and Cortel-Breeman 1970; Aguilera and Ganesan 1981) and other Nemaliales, such as Gloiophloea (Huisman 1987), Helminthocladia (Boillot 1971b) and Liagora (e.g., Brodie and Norris 1992).

The present study indicates that the development of tetrasporophytes and gametophytes in S. interrupta depends on light intensity, and is limited by low irradiance levels. The influence of the irradiance regime on initial tetrasporogenesis is reported for the first time for Scinaia, with development being accelerated under higher irradiance levels. The influence of light on the Scinaia life-cycle had been previously investigated by Ramus (1969) and van den Hoek and Cortel-Breeman (1970) for respectively $S$. confusa and $S$. complanata. The former author observed tetrasporangia development only under high irradiance levels whereas the study of van den Hoek and CortelBreeman (1970) was inconclusive. Production of apical utricles by the filamentous gametophyte (Fig. $4 b-c$ ) is also newly reported for the genus. This was observed in all culture regimes, but further development of gametophytes was not observed at the lowest irradiance level. Further studies in other species of Scinaia are needed and recommended to evaluate the persistence of this new development phase.

In the field, only fleshy gametophytes have been observed and they are restricted to warmer periods. However, considering the results of the present study and the time required for the $S$. interrupta life-cycle in vitro (5 to 11 months), it is likely that tetrasporophyte filaments and protonemal gametophytes also occur in natural environments.

Acknowledgments We thank López-Vivas J. M. for his support. We are grateful to N. Álvaro, A. Amaral, D. Torrão, S. Garcia, for their diving assistance, E. Rosas-Alquicira and M. Terra for technical assistance and F. Wallenstein, G. Martins, I. Tittley and three anonymous reviewers for their comments and suggestions. K. L.-C. acknowledges the scholarship from CONACYT \# 157904 and from the European Union Programmer of High Level Scholarships for Latin America No. E05D060520MX. We also thank the Marine Botany Laboratory staff of the UAC for their assistance. This work was partially supported by the CIRN (Centro de Investigação de Recursos Naturais) under the $\mathrm{PhD}$ thesis of the first author. 


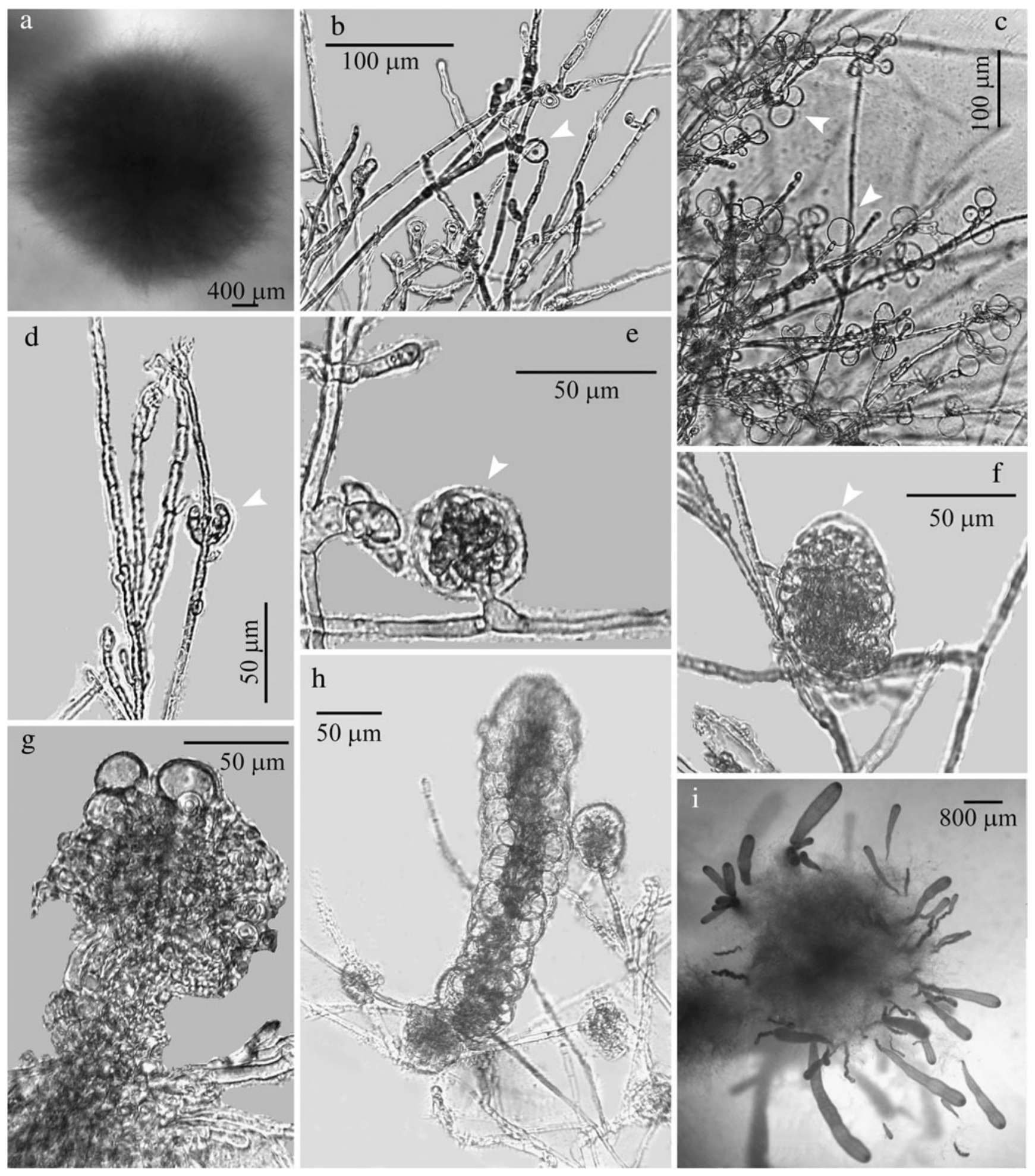

Fig. 4 S. interrupta gametophyte development. a Habit of protonemal gametophyte; b-c apical utricles on the protonemal gametophyte (arrowheads); d initial bud development (arrowhead); e-f enlarged pigmented multicellular aggregations (buds) with mucilage cover (arrowhead); g central filaments and utricle development; $\mathbf{h}$ fleshly gametophyte; i protonemal gametophyte hosting several fleshy outgrowths 


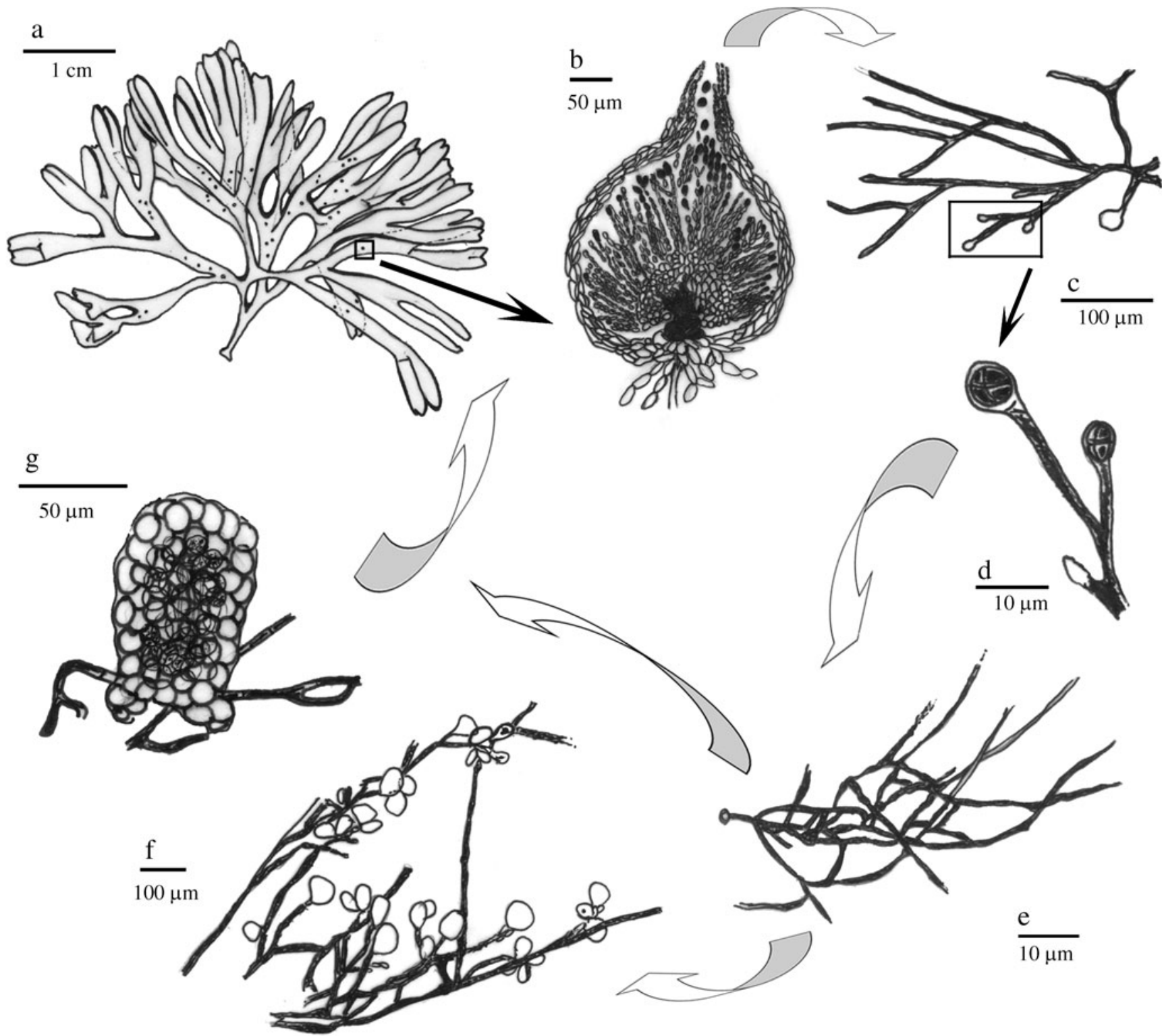

Fig. 5 Life-cycle of $S$. interrupta. a Fleshy gametophyte showing cystocarps scattered on the thallus; b cystocarp with released carpospores; c filamentous tetrasporophyte; d tetrasporangium; e filamentous protonemal gametophyte; $\mathbf{f}$ apical utricles in the filamentous protonemal gametophyte; $\mathbf{g}$ young fleshy gametophytes

Bivona, Rhodophycées (Némalionales). Compte Rendu Hebdomadaire des Séances de l'Académie des Sciences Paris Série D 268:273-275

Boillot A (1971a) Sur le cicle de Scinaia turgida Chemin. Bulletin Soc Botan France 16:68-69

Boillot A (1971b) Sur le cycle d'Helminthocladia calvadosii (Lamouroux) Setchell. Bull Soc Botan France 16:106-110

Brodie J, Norris JN (1992) Life history and morphology of Liagora aff. ceranoides (Liagoraceae, Rhodophyta) from the Florida keys. Phycologia 31:419-430

Guiry GM, Cunningham EM (1984) Photoperiodic and temperature responses in the reproduction of north-eastern Atlantic Gigartina acicularis (Rhodophyta: Gigartinales). Phycologia 23:357-367

Guiry MD, Guiry GM (2009) AlgaeBase. World-wide electronic publication. National University of Ireland, Galway. Searched on 26 May 2009. Available from: http://www.algaebase.org/ 
Holmgren PK, Holmgren NH (1998, continuously updated). Index Herbariorum: A global directory of public herbaria and associated staff. New York Botanical Garden's Virtual Herbarium. Available from: http://sweetgum.nybg.org/ih/

Huisman JM (1987) The taxonomy and life history of Gloiophloea (Galaxauraceae, Rhodophyta). Phycologia 26:167-174

Huisman JM, Borowitzka MA (1990) A revision of the Australian species of Galaxaura (Rhodophyta, Galaxauraceae), with a description of Tricleocarpa gen. nov. Phycologia 29:150-172

Kurihara A, Arai S, Shimada S, Masuda M (2005) The conspecificity of Galaxaura apiculata and G. hystrix (Nemaliales, Rhodophyta) inferred from comparative morphology and rbcL and ITS1 sequences. Eur J Phycol 40:39-52

León-Cisneros K, Gabriel D, Neto AI, Fredericq S, Riosmena-Rodríguez R (2007) Molecular characterization of the red algal genus Scinaia (Scinaiaceae, Nemaliales) from the Azorean Archipelago with morphological observations on S. interrupta. J Phycol 43:10

León-Cisneros K, Riosmena-Rodríguez R, Neto AI, HernándezCarmona G (2009) The red algal genus Scinaia (Nemaliales;
Rhodophyta) on the Gulf of California, Mexico: a taxonomic account. Phycologia 48:186-210

Maggs CA, Guiry MD (1982) The taxonomy, morphology and distribution of species of Scinaia Biv.-Bern. (Nemaliales, Rhodophyta) in north-western Europe. Nordic J Bot 2:517523

Ramus J (1969) The developmental sequence of the marine red alga Pseudogloiophloea in culture. University of California Publications in Botany 52:1-42

Umezaki I (1972) The life histories of some Nemaliales whose tetrasporophytes were unknown. In: Abbott IA, Kurogi M (eds) Contributions to the systematics of benthic marine algae of the North Pacific. Japanese Soc. Phycol, Kobe, pp 232-242

van den Hoek C, Cortel-Breeman AM (1970) Life-history studies on Rhodophyceae III. Scinaia complanata (Collins) Cotton. Acta Botanica Neerlandica 19:457-467

Vergés A, Utgé J, Rodríguez-Prieto C (2004) Life histories of Predaea ollivieri and P. pusilla (Nemastomatales, Rhodophyta). Eur J Phycol 39:411-421 